\title{
Doğu Karadeniz Bölgesindeki Partikül Madde Dağılımlarının Coğrafi Bilgi Sistemleri Yardımıyla Belirlenmesi
}

\author{
Kazım Onur Demirarslan ${ }^{1 *}$, Halil Akıncı \\ ${ }^{1}$ Artvin Coruh Üniversitesi Mühendislik Fakültesi Cevre Mühendisliği Bölümü, 08100, Artvin. \\ ${ }^{2}$ Artvin Çoruh Üniversitesi Mühendislik Fakültesi Harita Mühendisliği Bölümü, 08100, Artvin.
}

\section{Özet}

Doğu Karadeniz Bölgesi'ndeki plansız kentleşme, ulaşım ve sanayi gibi etkenler bölgede önemli olumsuz etkilere neden olmaktadır. Bu etkilerden biri de hava kirliliğidir. Hava kirliliği, kentlerde yaşam kalitesini azalmakta ve birçok sağllk sorununu da beraberinde getirmektedir. Özellikle kış aylarında isınma amacıyla kullanılan fosil yakıtlar bölgede önemli derecede hava kirliliğine yol açmaktadır. Çalışma alanında hava kirliliğine yol açabilecek önemli kaynaklardan biride Karadeniz sahil yoludur. Bu yol, Gürcistan sınırından itibaren Türkive'nin batısına kadar uzanan ve taşımacılıkta kullanılan önemli bir hattır. Yapılan çalıșmada, Doğu Karadeniz Bölgesi'nde yer alan, Artvin, Bayburt, Giresun, Gümüşhane, Ordu, Rize ve Trabzon illerindeki PM10 kirleticisinin hava kalitesi üzerindeki etkileri ve dağılımları, Coğrafi Bilgi Sistemleri (CBS) yardımıyla üretilen haritalarla incelenmiştir. Hava kalitesiyle ilgili veriler, Çevre ve Şehircilik Bakanlı̆̆ı'na ait ölçüm istasyonlarında ölçülen 2010-2015 yılları arasındaki saatlik verilerdir. Çalışma sonuçlarına göre, belirtilen tarih aralığında, Trabzon ve Gümüşhane illerinin tüm mevsimlerde, Bayburt ilinin yaz, sonbahar ve kıs aylarında, Ordu'nun ise özellikle sonbahar aylarında PM10 konsantrasyonunun yüksek olduğu belirlenmiştir.

Anahtar Sözcükler

CBS, Doğu Karadeniz Bölgesi, Hava Kalitesi, PM10

\section{Determination of Particulate Matter Dispersion in Eastern Black Sea Region Using Geographical Information Systems}

\begin{abstract}
Factors like unplanned urbanization, transportation and industry in Eastern Black Sea cause significant adverse effects in this region. One of these effects is the air pollution. Air pollution reduces the life quality in cities and also it brings about many health problems. Especially, in winter, fossil fuels are used for the purpose of commercial heating and these fuels cause serious air pollution in the region. One of the important sources which may lead to air pollution in research area is coastal road of Black Sea. This road extends from borderline of Georgia to western Black Sea Region of Turkey and is an important route for transportation. The effects and dispersions of PM10 pollutant in the provinces of Artvin, Bayburt, Giresun, Gümüşhane, Ordu, Rize and Trabzon located along the Eastern Black Sea Region were investigated using maps generated by Geographic Information Systems (GIS). Data related to air quality was obtained from the hourly measurements of the stations used by the Ministry Environment and Urban Planning between 2010 and 2015. According to the study results, it was determined that, in specified date range, the concentrations of PM10 were high; in all seasons for Trabzon and Gümüşhane, in the summer, autumn and winter seasons for Bayburt and especially in the autumn for Ordu.
\end{abstract}

$\underline{\text { Keywords }}$

GIS, Western Black Sea Region, Air Quality, PM10

\section{Giriş}

Günümüzde hızla büyümekte olan kentleşme beraberinde önemli sağlık, çevresel, ekonomik ve sosyal problemler meydana getirmektedir. Bu problemlerden bir tanesi de hava kirliliğidir ve Dünya'da insan sağlı̆̆ını etkileyen en önemli çevresel faktörlerin başında gelmektedir (Russo vd. 2014; Giannouli vd. 2011; Aguilera vd. 2013). Hava kirliliği, "atmosferin fiziksel, biyolojik ve/veya kimyasal yapısının değişmesi” şeklinde tanımlanmaktadır (URL-1 2016). Şehirlerdeki hava kirliliğinin hava kalitesi üzerine etkileri, gerek topoğrafik farklılıklar ile meteorolojik koşullar gerekse de kirletici emisyonların karakteristikleri nedeniyle oldukça önemlidir (Parrish vd. 2011; Guttikunda ve Jawahar 2012). Hava kirleticileri gaz, katı partiküller ve sıvı damlacıklar şeklinde olabilmektedir. Bu kirleticiler doğal veya yapay kaynaklardan atmosfere verilmektedir. Volkanik aktiviteler, orman yangınları, organik çürümeler ve rüzgara bağlı toz bulutları doğal kirletici kaynaklara örnektir. Taşımacılık (motorlu taşıtlar, uçaklar, gemiler vs.), fosil yakıt kullanımı, endüstriyel prosesler, tarımsal faaliyetler, katı atık depolama sahaları gibi insan aktiviteleri sonucu olan 
kaynaklar ise yapay hava kirleticilere örnek olarak gösterilebilirler (Dimitriou ve Christidou 2011; Demirarslan 2015). Hava kirleticileri insanlarda uzun dönemli sağlık sorunları ile erken ölümlere sebep olmaktadır. Hava kalitesinin azalmasının insan sağlığı üzerindeki etkileri önemli derecede fazladır ve Dünya Sağlık Örgütü (WHO)'nün tahminlerine göre hava kirliliğinin yol açtı̆̆ı hastalıklardan her yıl dünya çapında 800 bin kişi hayatını kaybetmektedir (Giannouli vd. 2011; Bentajeb vd. 2014). Kentlerde hava kalitesinin azalması sonucu sağlık sorunlarının giderek artması üzerine Avrupa Birliği ile A.B.D. Çevre Koruma Ajansı (Environmental Protection Agency) tarafından ortam hava kalitesi standartlarına $\mathrm{O}_{3}, \mathrm{NO}_{2}, \mathrm{SO}_{2}, \mathrm{PM} 2,5$ ve PM10 gibi kirleticiler de eklemiştir (Baldasano vd. 2011).

Hava kirleticilerden biri olan partikül madde (PM), havada asılı halde bulunan katı-sıvı partiküllerin karışımı olup potansiyel olarak insan sağlığına zararlıdır ve solunum sistemlerinde rahatsızlıklara yol açabilmektedir. Kimyasal bileşimi ve boyutu zamana, yere göre değişebilmektedir ve karmaşık heterojen yapıdaki önemli kirleticilerden biridir (URL-2 2016). Literatürde PM kaynaklarının trafik \%25, yanma \%22, evsel ısınma \%20, doğal \%18 ve sanayi \%15 olduğu belirtilmektedir (Demirarslan 2016). PM mikron düzeyinde ölçeklendirilir. En büyük PM çap1 $10 \mu \mathrm{m}$ düzeyindedir. PM10, partikül madde çapının $10 \mu \mathrm{m}$ ve daha az olduğunu ifade etmektedir. Bu çalışmada, Doğu Karadeniz Bölgesi'ndeki PM10 dağılımlarının Coğrafi Bilgi Sistemleri (CBS) yardımıyla belirlenmesi amaçlanmıştır.

\section{Materyal ve Metot}

$\mathrm{Bu}$ çalışmada, Doğu Karadeniz Bölgesi'ndeki PM10 konsantrasyonunun mevsimlere göre dağılımı incelenmiştir. Çalışma alanı, Doğu Karadeniz Bölgesi sınırları içerisinde kalan Artvin, Bayburt, Giresun, Gümüşhane, Ordu, Rize ve Trabzon illerini kapsamaktadır (Şekil 1). Bölgenin yüzölçümü yaklaşık olarak 39483 km² dir. Konsantrasyon ölçüm verileri, çalışma alanındaki illerde bulunan T.C. Çevre ve Şehircilik Bakanlığı'na ait ölçüm istasyonlarından elde edilmiştir ve 2010-2015 y1llarına ait verilerdir. Bu istasyonlar incelendiğinde, 2010-2015 y1lları arasında Artvin, Bayburt, Gümüşhane, Rize ve Trabzon'da 1, Ordu'da 2010-2014 yılları arasında 2, 2015 yılında 4 adet istasyon olduğu belirlenmiştir. Söz konusu veriler, Bakanlığın "Hava Kalitesi İzleme İstasyonları" Web sitesinden (http://www.havaizleme.gov.tr) alınmış olup ilkbahar, yaz, sonbahar ve kış ayları olmak üzere mevsimlere ayrılmış ve mevsimlere göre ortalama konsantrasyon değerleri hesaplanmıştır.

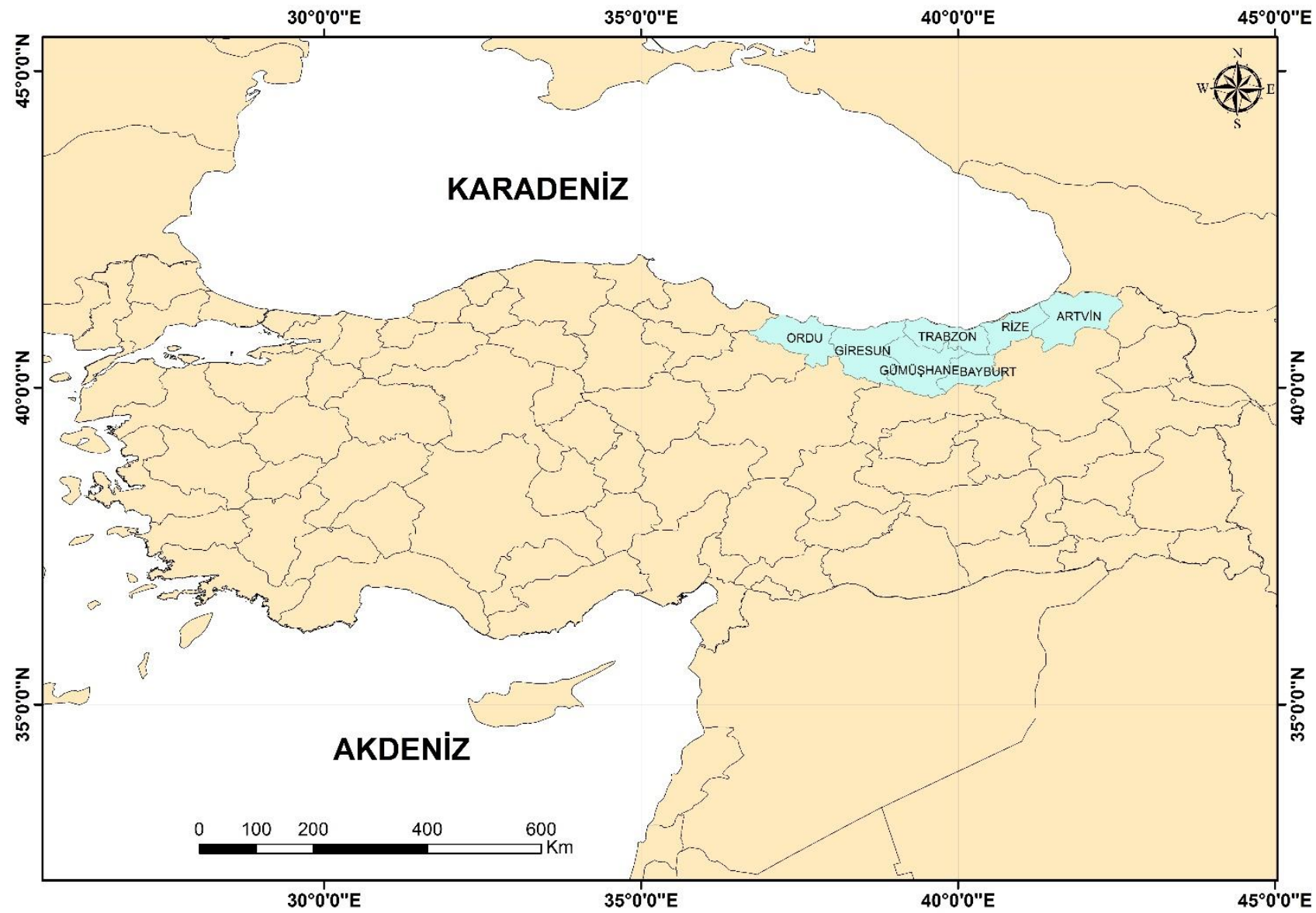

Şekil 1: Çalışma alanı haritası 
ArcGIS 10.2.1 CBS yazılımında ölçüm istasyonlarının koordinatları kullanılarak bir nokta katmanı yaratılmış ve mevsimsel ortalama konsantrasyon değerleri öznitelik verisi olarak bu nokta katmanına eklenmiştir. ArcGIS CBS yazılımında “Ters Mesafe Ağırlıklı Enterpolasyon Yöntemi (Inverse Distance Weighted, IDW)” kullanılarak Doğu Karadeniz Bölgesinin mevsimsel PM10 dağılım haritaları üretilmiştir. Dağılım haritalarının yorumlanmasında kullanılmak amaciyla bölgeye ait rüzgâr gülleri oluşturulmuştur. Bu amaçla, Meteoroloji Genel Müdürlüğü Meteorolojik Veri Arşiv Sisteminden il merkezlerinde bulunan meteorolojik istasyonlardaki 2010-2014 yılları rüzgâr hızı ve rüzgâr yönü verileri elde edilmiştir. Çalışma bölgesinde hava kalitesinden etkilenen nüfus verileri TÜíK'in Adrese Dayalı Nüfus Kayıt Sistemi’nden temin edilmiştir (Tablo 1).

Tablo 1: Çalışma alanındaki il merkezlerinin nüfus verileri

\begin{tabular}{|l|r|r|r|r|r|r|}
\hline İl & $\mathbf{2 0 1 0}$ & $\mathbf{2 0 1 1}$ & $\mathbf{2 0 1 2}$ & $\mathbf{2 0 1 3}$ & $\mathbf{2 0 1 4}$ & $\mathbf{2 0 1 5}$ \\
\hline Artvin & 89960 & 91886 & 93673 & 94316 & 98039 & 99359 \\
\hline Bayburt & 37537 & 40354 & 40564 & 40836 & 45488 & 46276 \\
\hline Giresun & 245381 & 248547 & 248957 & 251811 & 270615 & 275554 \\
\hline Gümüşhane & 61162 & 64082 & 67514 & 70667 & 87978 & 99508 \\
\hline Ordu & 404390 & 409288 & 423295 & 731452 & 724268 & 728949 \\
\hline Trabzon & 415652 & 421504 & 426882 & 758237 & 766782 & 768417 \\
\hline Rize & 197520 & 202631 & 207631 & 204194 & 211495 & 215596 \\
\hline
\end{tabular}

Çalışma alanında hava kalitesini etkileyen sebepleri belirlemek için adı geçen illerin il çevre ve durum raporları incelenmiştir. Buna göre, Artvin ilinde çizgisel kaynak (trafik) ile kışın ısınmadan kaynaklı fosil yakıt kullanımı hava kirliliği kaynağı olarak gösterilmektedir (URL-3 2012; URL-4 2013; URL-5 2014). Bayburt ilinde ise kışın 1sınmadan kaynaklı fosil yakıt kullanımı ile çizgisel kaynaklar ve sanayi tesisleri hava kirletici kaynaklar arasındadır (URL-6 2011; URL-7 2012; URL-8 2013; URL-9 2014). Giresun il çevre ve durum raporunda ise ilde özellikle kış aylarında 1sınmadan kaynaklı hava kirliliğinin olduğu belirtilmekte ve bunun da yanlış yakma tekniklerinin uygulanması, kullanılan yakma sistemleri, işletme (kazan, baca vb.) bakımlarının düzenli olarak yapılmaması, atmosferik koşullar gibi sebeplerden dolayı olduğu bildirilmektedir. Yine aynı raporda, ilde endüstriyel emisyon kirliliği yapan kuruluşların sayılarının az olması ve sanayi tesislerinin şehir merkezi dışında bulunmalarından dolayı ilin hava kalitesi üzerine etkisinin az olduğu belirtilmiştir. İlin topoğrafik yapısının çanak şeklinde olması özellikle kış aylarında hava kirleticilerinin yoğun olarak hissedilmesine neden olmaktadır. Ayrıca, Giresun il merkezinden geçen Karadeniz Sahil Yolu çizgisel kaynak olarak değerlendirilebilmektedir (URL-10 2011, URL-11 2012, URL-12 2013, URL-13 2014). Gümüşhane il çevre ve durum raporlarına göre ise ildeki sanayi, binalar ve özellikle motorlu taşıtlar hava kirliliğinde artışlara neden olmuştur. Yine aynı raporlara göre Gümüşhane ilinde trafik ve sanayi kaynaklı hava kirliliği ilin hava kalitesi üzerinde pek değişikliğe neden olmasa bile 1sınma kaynaklı kirlilik söz konusudur (URL-14 2010, URL-15 2011, URL-16 2012, URL-17 2013, URL-18 2014). Ordu ilinde ise konutlarda 1sınma amaçli kullanılan yakıtların ve mobil kaynakların hava kirletici kaynaklardan olduğu belirlenmiştir. Ayrıca ilin sınırlarından geçen D 010 karayolunun bazı kesimlerinde meydana gelen trafik yoğunluğu ve buna bağlı trafik sıkışıklıkları hava kalitesi üzerinde önemli olumsuz etkilere sebep olmaktadır (URL-19 2011, URL-20 2012, URL-21 2013). Rize ilinde hava kirliliği kaynağ1 olarak konutlar ve çay üretim tesisleri başta gelmektedir. Ek olarak il sınırları içerisinden geçen Karadeniz Sahil Yolunun da hava kalitesi üzerine olumsuz etkileri bulunmaktadır. Kış aylarında ise kömür, odun ve kalorifer yakıtı 1sınma amaçlı olarak kullanılmaktadır. Bu da ısınma sonucu oluşan hava kirliliğinin nedenleri arasında gösterilmektedir (URL-22 2010, URL-23 2011, URL-24 2012, URL-25 2013, URL-26 2014). Trabzon ilinde ise hava kalitesini etkileyen unsurlar arasında kentleşme ve trafik sayılmaktadır (URL-27 2010, URL-28 2011 , URL-29 2012, URL-30 2013, URL-31 2014).

\section{Bulgular}

Çalışma alanında bulunan Hava Kalitesi Ölçüm İstasyonlarından alınan ve 2010-2015 yıllarını kapsayan PM10 verileri CBS veritabanına girilmiş ve ArcGIS 10.2.1 yazılımında "Ters Mesafe Ağırlıklı Enterpolasyon Yöntemi (Inverse Distance Weighted, IDW)" kullanılarak mevsimsel PM10 dağılım haritaları üretilmiştir. Dağılım haritalarının yorumlanması için bölgeye ait rüzgar gülleri ise il merkezlerinde bulunan meteorolojik istasyonlardaki veriler yardımıyla çizilmiştir. Bu veriler saatlik bazda yıllık verilerdir ve 2010-2014 yıllarını kapsamaktadır. Rüzgar güllerinin çiziminde Lakes Environmental Software tarafından hazırlanan WRPLOT View 7.0.0 programından yararlanılmıştır. Program yardımıyla rüzgar yönü, frekans analizi gibi sonuçlar alınmakta, zamana ve yere bağlı olarak rüzgar sınıfı, yönü ve hızı belirlenebilmektedir (URL-32 2016). Çalışma alanının WRPLOT View programı ile üretilen rüzgar gülleri Şekil 2'de, ortalama rüzgar hızları ise Tablo 2'de verilmektedir.

Rüzgar gülleri incelendiğinde, çalışma alanında hakim rüzgar yönlerinin her ilde farklı olduğu anlaşılmıştır. Bu durum da bölgedeki hava kirliliği dağılımlarında etkili olmaktadır. Ortalama rüzgar hızlarının en fazla olduğu il 9,79 km/saat ile Trabzon'dur. Bunun yanında sakin koşulların yaşandığı en fazla zaman Rize'de görülmektedir. Bölgede hava kirliliği dağılımında etkili olabilecek diğer bir etkende alanın topoğrafik yapısıdır. Karadeniz Bölgesinin bir özelliği 
olarak çalışma alanının kuzey kesiminde yükseklikler deniz seviyesindedir ve güney kesimlerine gidildikçe yükseklikler hızla artmaktadır. Bu durumda kirliliğin şehir merkezlerinden dağılmasını engelleyebilmektedir.

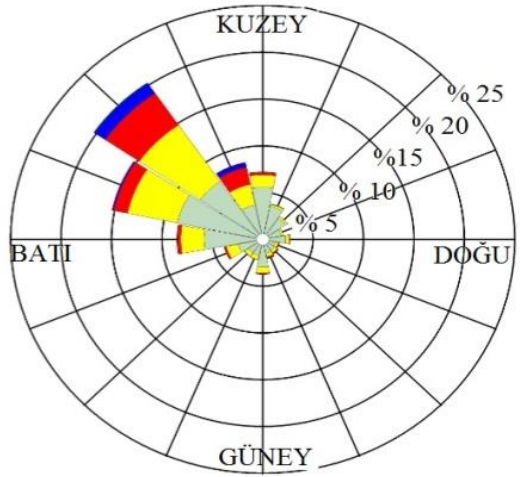

a. ARTVIN

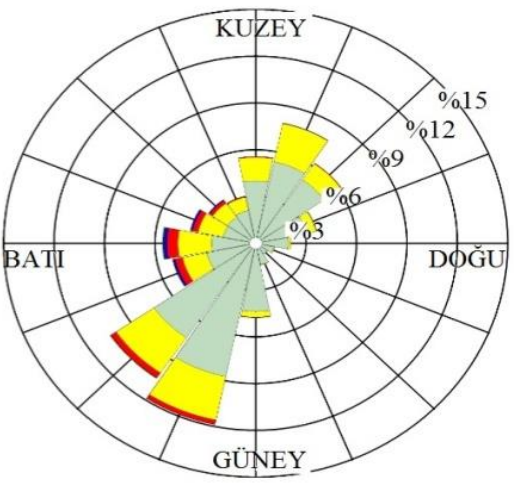

c. GIRESUN

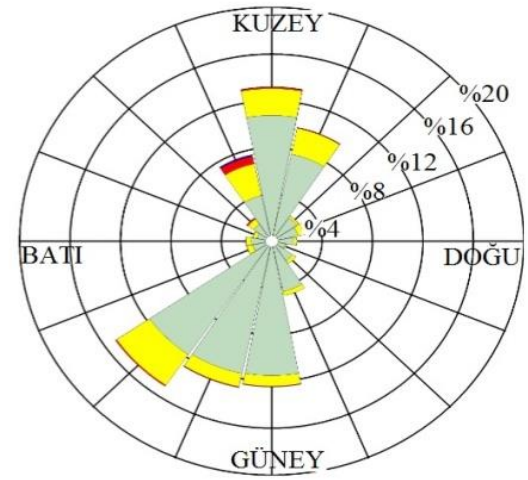

e. ORDU

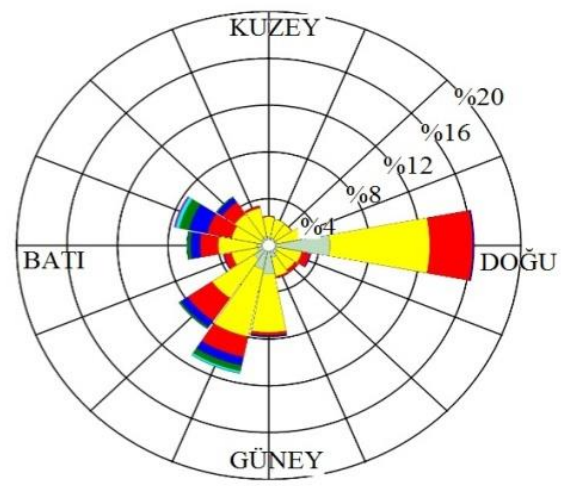

g. TRABZON

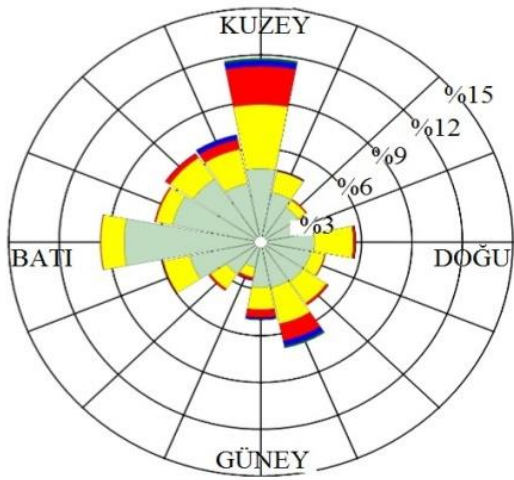

b. BAYBURT

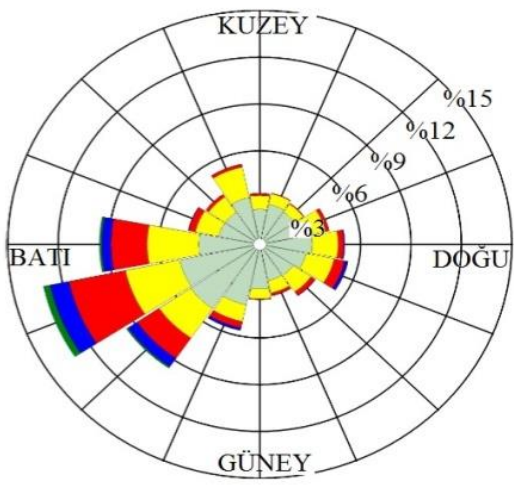

d. GÜMÜȘHANE

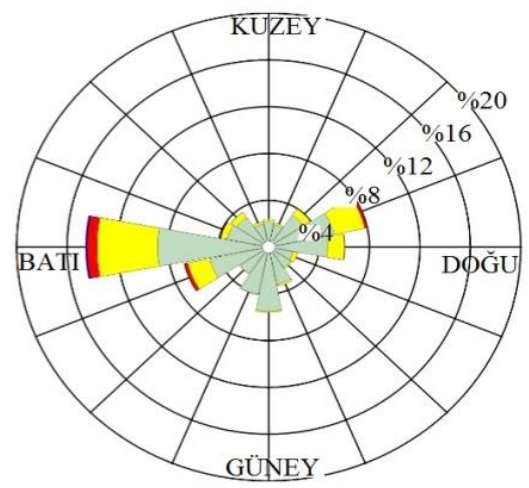

f. RİZE

RÜZGAR HIZI

$(\mathrm{m} / \mathrm{sn})$

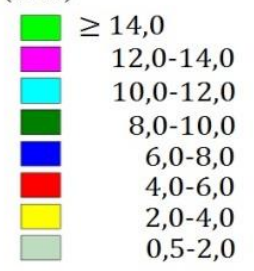




\subsection{Illkbahar Mevsimi Hava Kalitesi Dağılımları}

Çalışma alanı içerisinde bulunan illerdeki PM10 verilerinin ilkbahar mevsimi ortalaması Mart, Nisan ve Mayıs ayları verileri kullanılarak hesaplanmıştır. Bu ortalamaların ArcGIS programı yardımıyla dağılımları haritalandırılmış ve Şekil 3 ve Şekil 4 de verilmiştir. 2010 yllı ilkbahar haritası incelendiğinde en yüksek konsantrasyona sahip alanlar arasında $\left(53,60 \sim 63,40 \mu \mathrm{g} / \mathrm{m}^{3}\right)$ Trabzon, Rize illerinin büyük kesimi ile Ordu il merkezinin olduğu görülmektedir. İkinci en yüksek konsantrasyon değerine sahip $\left(47,38 \sim 53,60 \mu \mathrm{g} / \mathrm{m}^{3}\right)$ alanlar ise Bayburt'un tamamı ve Ordu ilinin büyük bir kesimidir. Artvin ilinin tamamı ile Giresun il merkezi en düşük PM10 konsantrasyonuna $\left(23,65 \sim 32,23 \mu \mathrm{g} / \mathrm{m}^{3}\right)$ sahip bölgedir.

2011 yılında Trabzon, Gümüşhane ve Ordu il merkezleri 56,21 63,33 $\mu \mathrm{g} / \mathrm{m}^{3}$ aralı̆̆ında en fazla PM10 konsantrasyonuna sahip iller olmuştur. Artvin, Bayburt, Giresun il merkezleri ve Rize $30,92 \sim 43,50 \mu \mathrm{g} / \mathrm{m}^{3}$ civarındaki konsantrasyon ile en düşük seviyede takip etmiştir. Ordu iç kesimleri ile Gümüşhane il merkezi dışında kalan noktalarda ise ikinci seviyede konsantrasyon dağılımı $\left(50,24 \sim 56,21 \mu \mathrm{g} / \mathrm{m}^{3}\right)$ meydana gelmiştir.

2012 yılı ilkbahar ayları PM10 konsantrasyon ortalaması en yüksek bölge Gümüşhane il merkezidir (63,17 79,72 $\left.\mu \mathrm{g} / \mathrm{m}^{3}\right)$. Trabzon ilinin tamamına yakını ile Bayburt ilinin tüm kesimleri 49,67 63,17 $\mu \mathrm{g} / \mathrm{m}^{3}$ konsantrasyon aralığında ikinci en yüksek seviyeye ulaşmıştır. Ordu ili üçüncü sıra konsantrasyon seviyesindedir ve son seviyedeki iller Giresun, Rize ve Artvin'dir.

2013 y1lında diğer yıllarda olduğu gibi Trabzon ve Gümüşhane il merkezi en yüksek seviyededir $(60,59 \sim 83,95$ $\left.\mu \mathrm{g} / \mathrm{m}^{3}\right)$. Bayburt ilinin tamamı ve Ordu il merkezi ikinci en yüksek seviyede konsantrasyona sahiptir. Artvin ile Giresun $17,0 \sim 37,76 \mu \mathrm{g} / \mathrm{m}^{3}$ ile son siradadır.

İlkbahar ayları PM10 konsantrasyon ortalamalarının incelendiği 2014 y1lı haritasında Trabzon ve Gümüşhane $52,16 \sim 61,28 \mu \mathrm{g} / \mathrm{m}^{3}$ ile en yüksek seviyeye ulaşmıştır. İncelenen haritada Bayburt il merkezi üçüncü seviye konsantrasyona sahipken Ordu ve Giresun illerinin tamamı ikinci seviye konsantrasyona ulaşmıştır. 2014 yıllarında Artvin ve Rize illeri en düşük konsantrasyon seviyelerindedir $\left(20,66 \sim 37,61 \mu \mathrm{g} / \mathrm{m}^{3}\right)$.

2015 yılı ilkbahar ortalaması haritasında ise en yüksek seviyenin Trabzon il merkezinde olduğu görülmektedir $\left(53,0 \sim 64,18 \mu \mathrm{g} / \mathrm{m}^{3}\right)$. Ordu, Giresun, Gümüşhane ve Bayburt illerinin tamamı ikinci seviye ve Rize ili üçüncü seviyededir. Artvin'in PM10 konsantrasyon seviyesi ise son sırada hesaplanmıştır.

\subsection{Yaz Mevsimi Hava Kalitesi Dağılımları}

Çalışma alanında hava kalitesi dağılımları yapılırken yaz ayları ortalaması olarak Haziran, Temmuz ve Ağustos aylarında ölçülen veriler kullanılmıştır. Elde edilen dağılım haritaları Şekil 5 ve Şekil 6 da verilmiştir.

2010 yılı yaz ortalaması haritası dikkate alındığında 78,51 96,73 $\mu \mathrm{g} / \mathrm{m}^{3}$ aralıkla Trabzon il merkezinin diğer illere göre yüksek seviyede konsantrasyona sahip olduğu görülmektedir. Bu konsantrasyon Trabzon'un iç kesimlerine kadar dağılma eğilimi göstermiştir. Çalışma alanındaki diğer illerde ise $24,16 \sim 52,62 \mu \mathrm{g} / \mathrm{m}^{3}$ konsantrasyon aralığı ile en düşük seviye olduğu görülmektedir.

2011 yaz ortalaması dağılım haritasında en yüksek konsantrasyona sahip il Gümüşhane olmuştur (46,13 57,05 $\left.\mu \mathrm{g} / \mathrm{m}^{3}\right)$. 38,73 46,13 $\mu \mathrm{g} / \mathrm{m}^{3}$ konsantrasyon seviyesiyle ikinci sırada yer alan bölge Ordu il merkezi ve Gümüşhane çevresidir. Artvin ili, Trabzon merkezi ve Ordu'nun iç kesimleri 32,85 38,75 $\mu \mathrm{g} / \mathrm{m}^{3}$ konsantrasyon seviyesi ile üçüncü sıradadır. Giresun, Rize ve Bayburt diğer illere nazaran daha düşük PM10 seviyesine sahiptir.

Gümüşhane ve Bayburt illerinin 38,64 47,10 $\mu \mathrm{g} / \mathrm{m}^{3}$ konsantrasyon seviyesiyle en yüksek konsantrasyona sahip olduğu 2012 yılı yaz ayları ortalaması haritasında, Trabzon'un tamamı ile Ordu il merkezinde ikinci seviyede konsantrasyon görülmüş̧ür. Artvin ilinin tamamı, Rize ve Ordu'nun iç kesimleri 24,59 31,39 $\mu \mathrm{g} / \mathrm{m}^{3}$ ile üçüncü seviyede konsantrasyona sahiptir. Giresun ve Rize merkezde en düşük seviyede konsantrasyon hesaplanmıştır.

2013 yılı yaz ortalaması haritasında Trabzon ve Gümüşhane illeri 39,29 51,76 $\mu \mathrm{g} / \mathrm{m}^{3}$ ile en yüksek konsantrasyona sahip illerdir. İkinci en yüksek konsantrasyona sahip $\left(32,56 \sim 39,29 \mu \mathrm{g} / \mathrm{m}^{3}\right)$ iller arasinda ise Bayburt, Rize ve Ordu sayılabilmektedir. Artvin ili 26,49 32,56 $\mu \mathrm{g} / \mathrm{m}^{3}$ lük konsantrasyonla üçüncü sırada, Giresun il merkezi ise son sırada konsantrasyon seviyesine sahip il olmuştur.

2014 yılında Gümüşhane il merkezinde 43,04 49,60 $\mu \mathrm{g} / \mathrm{m}^{3}$ değerle en yüksek konsantrasyon görülmektedir. Giresun, Trabzon illerinin büyük bir kısmı ile Bayburt ilinin batı kesiminde ikinci seviyede konsantrasyon hesaplanmıştır $\left(38,54 \sim 43,04 \mu \mathrm{g} / \mathrm{m}^{3}\right)$. Ordu ilinin tamamı ve Bayburt'un doğu kesimi 31,60 38,54 $\mu \mathrm{g} / \mathrm{m}^{3}$ konsantrasyon seviyesi ile üçüncü sıradaki, Rize ve Artvin illeri ise en düşük PM10 konsantrasyonuna sahip iller olduğu anlaşılmıştır.

Bayburt il merkezindeki konsantrasyonun en yüksek seviyede olduğu 2015 yllında $\left(45,01 \sim 56,07 \mu \mathrm{g} / \mathrm{m}^{3}\right)$, Gümüşhane ilinin doğusu ve Ordu ilinin batı kesimi 37,50 45,01 $\mu \mathrm{g} / \mathrm{m}^{3}$ konsantrasyon seviyesi ile ikinci en yüksek konsantrasyona sahip alanlar olmaktadır. Ordu ilinin güneyi, Giresun'un tamamı ve Trabzon'un büyük bir bölümünde üçüncü yüksek konsantrasyon seviyesi hesaplanmıştır $\left(33,16 \sim 37,50 \mu \mathrm{g} / \mathrm{m}^{3}\right)$. Rize ve Artvin illerinin tamamı ile Ordu il merkezi en düşük konsantrasyona sahip alanlardır $\left(22,49 \sim 28,42 \mu \mathrm{g} / \mathrm{m}^{3}\right)$. 

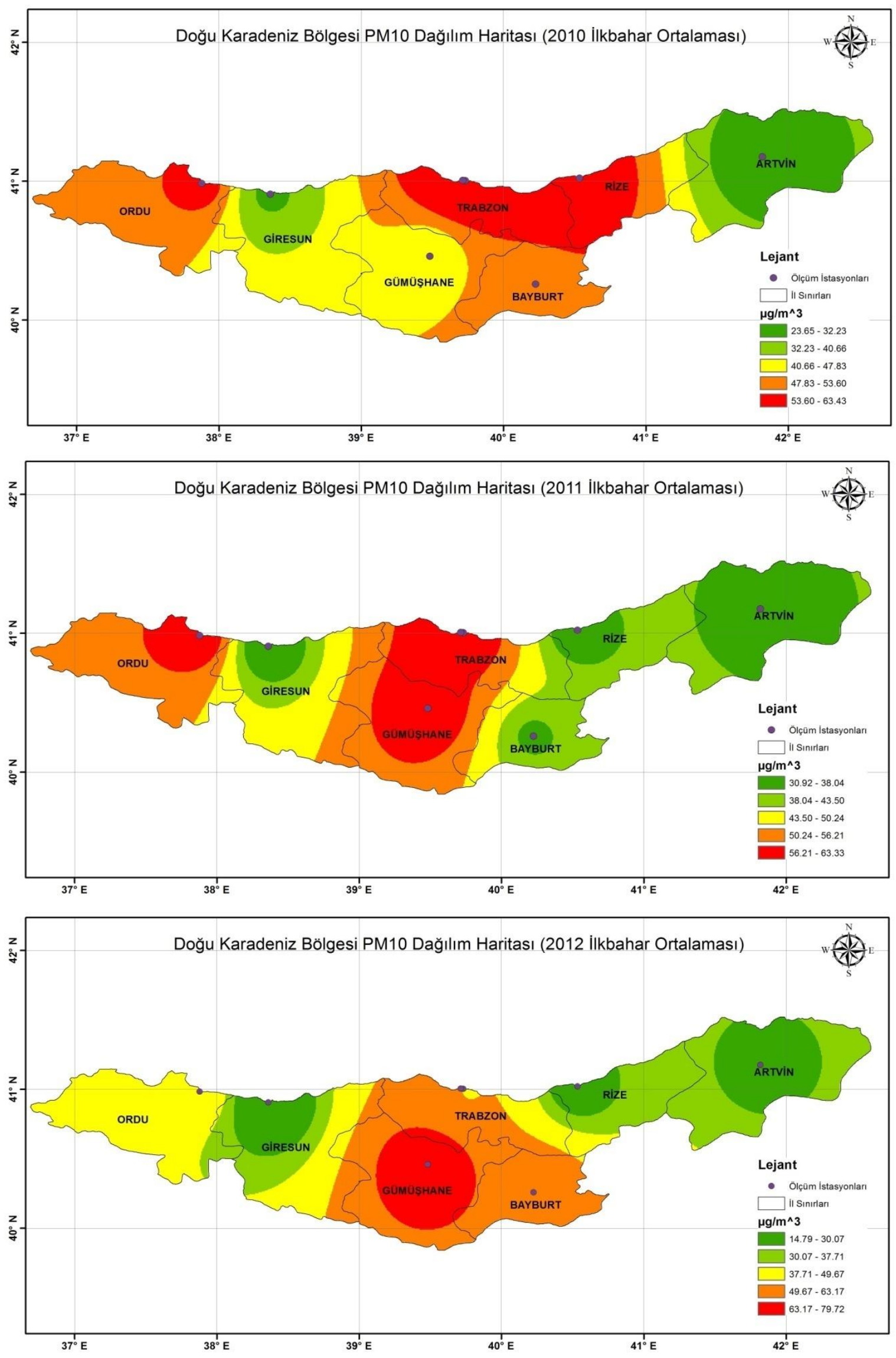

Şekil 3: Çalışma alanı ilkbahar mevsimi ortalaması PM 10 dağılımları (2010-2012 yılları) 

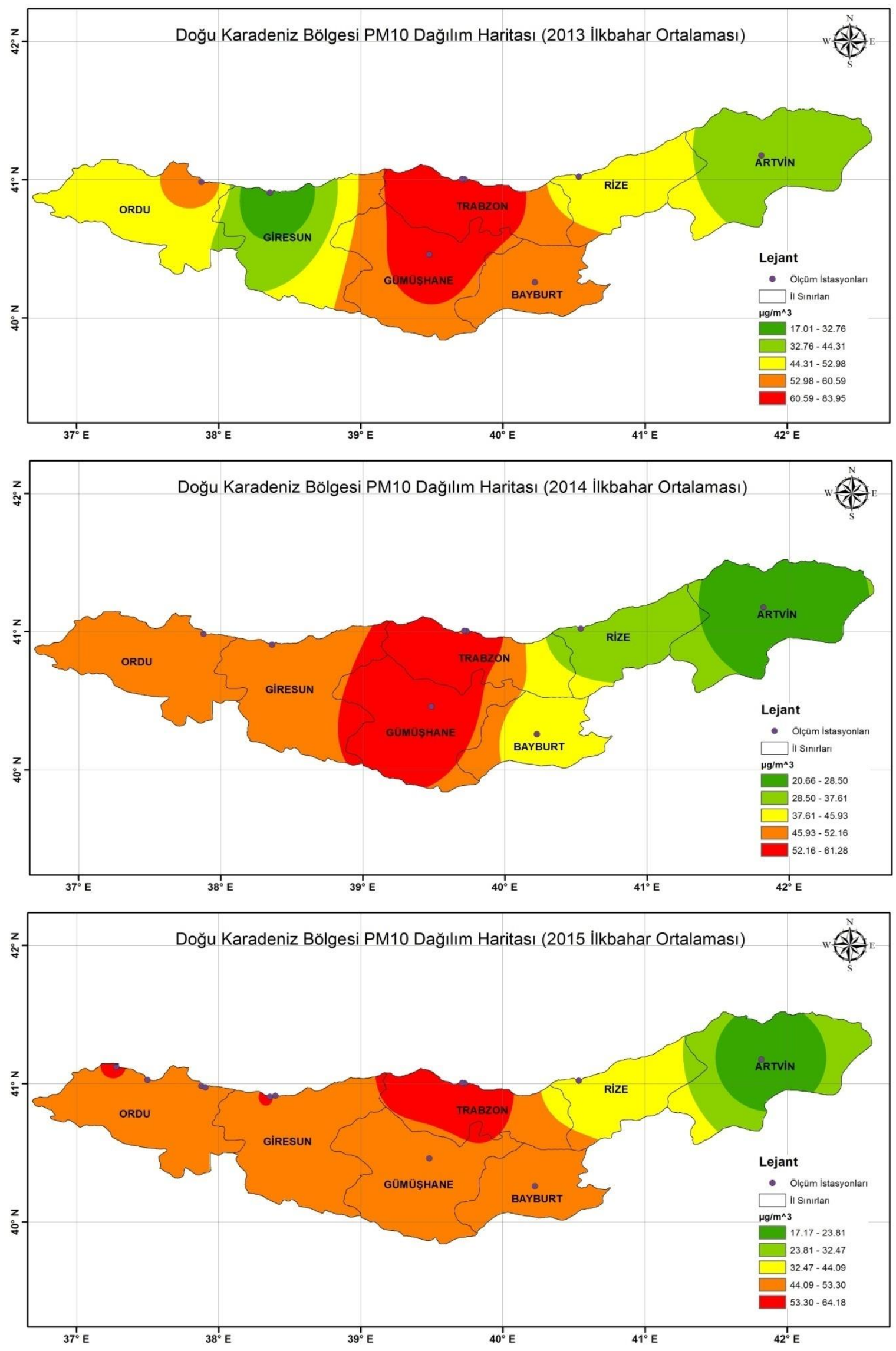

Şekil 4: Çalışma alanı ilkbahar mevsimi ortalaması PM 10 dağılımları (2013-2015 yılları) 

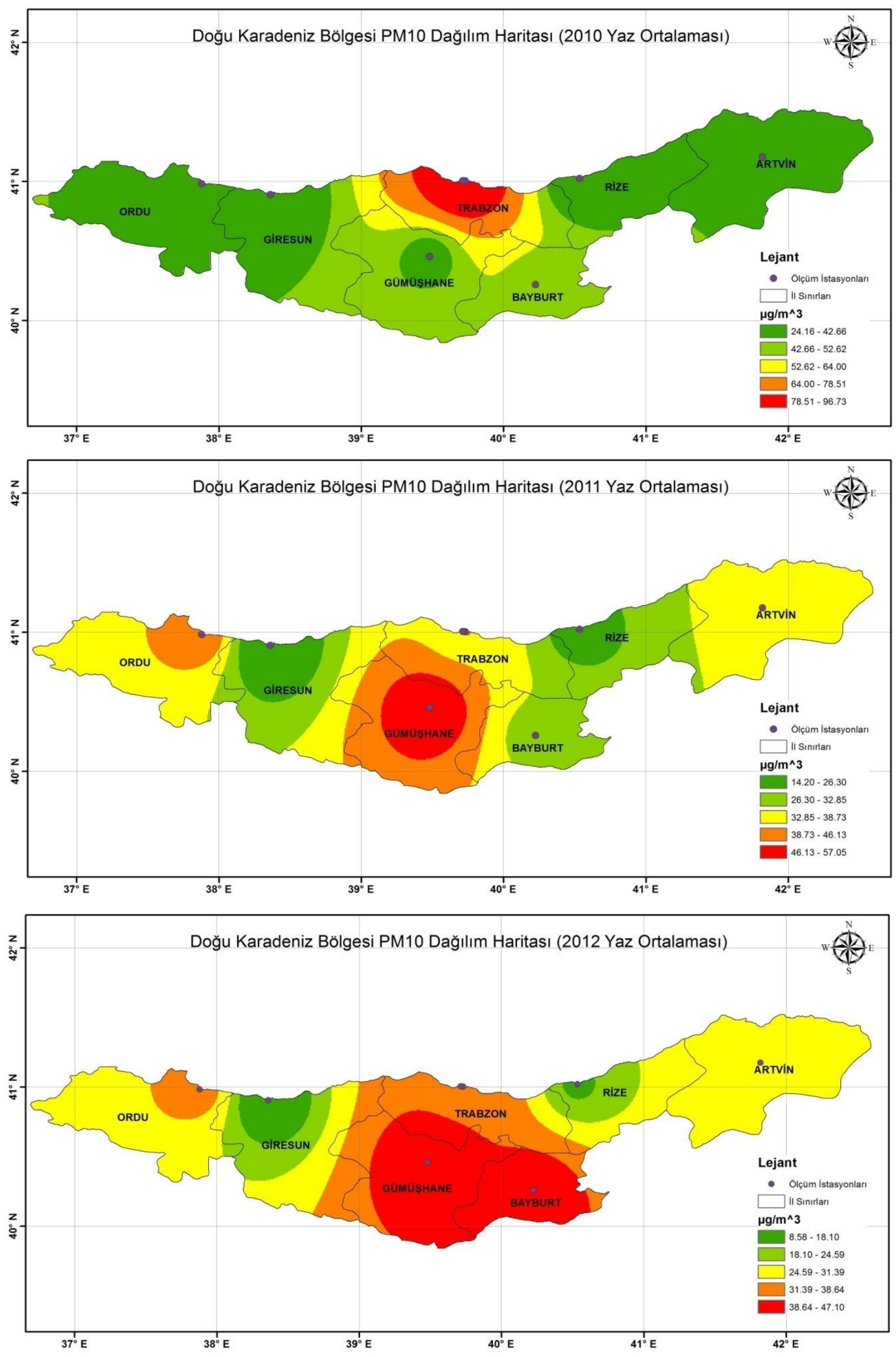

Şekil 5: Çalışma alanı yaz mevsimi ortalaması PM 10 dağılımları (2010-2012 yılları) 

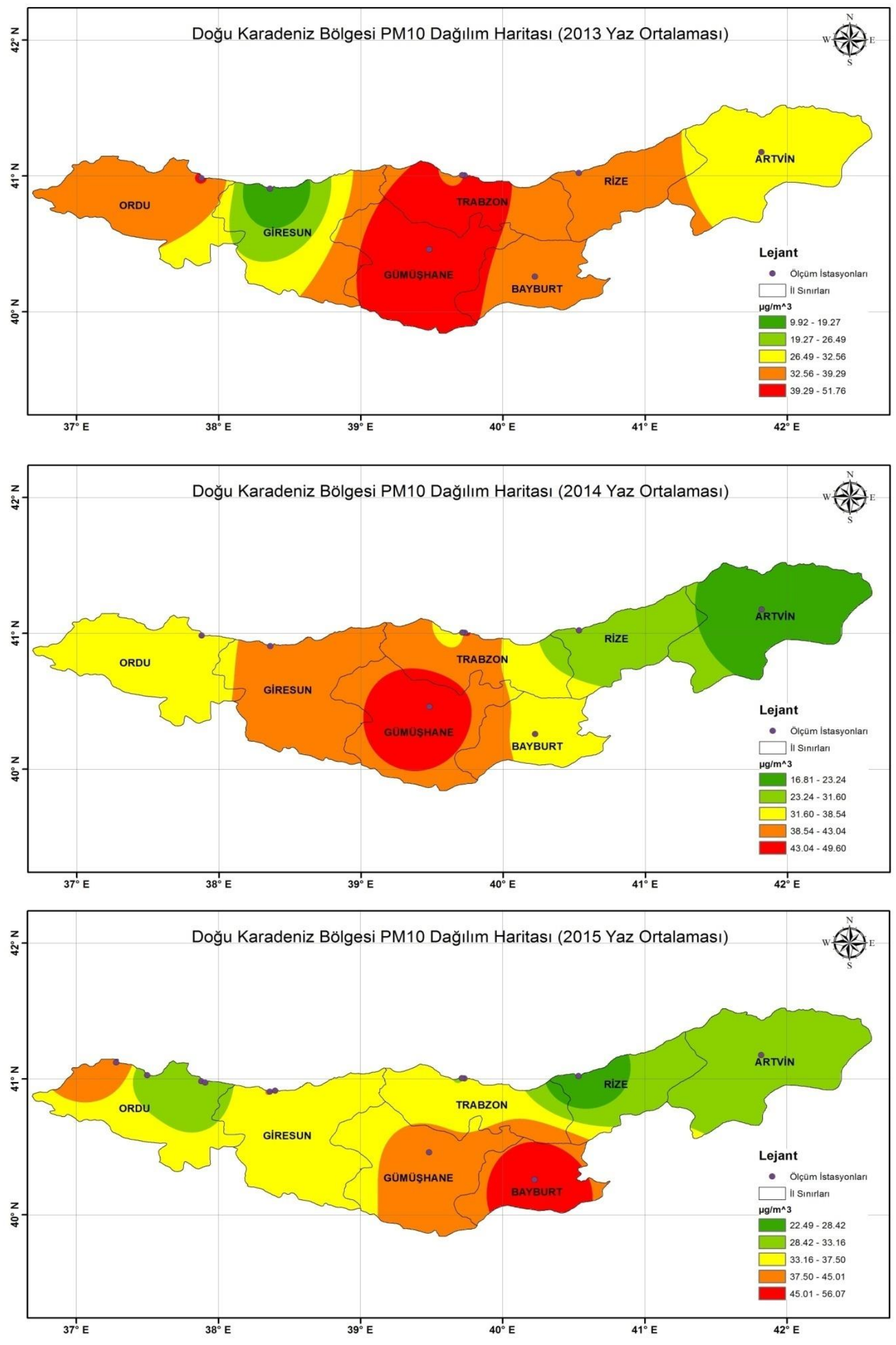

Şekil 6: Çalışma alanı yaz mevsimi ortalaması PM 10 dağılımları (2013-2015 yılları) 


\subsection{Sonbahar Mevsimi Hava Kalitesi Dağılımları}

Çalışma alanında sonbahar mevsimi hava kalitesi dağılımları yapılırken ortalama değer olarak Eylül, Ekim ve Kasım aylarında ölçülen veriler kullanılmıştır. Elde edilen dağılım haritaları Şekil 7 ve Şekil 8 de verilmiştir.

2010 y1lı sonbahar mevsimi haritası incelendiğinde en yüksek PM10 konsantrasyonunun çalışma alanı içerisinde Trabzon ve Bayburt olmak üzere iki ilde fazla olduğu görülmektedir $\left(72,88 \sim 110,90 \mu \mathrm{g} / \mathrm{m}^{3}\right)$. Diğger taraftan, Gümüşhane ikinci seviyede PM10 konsantrasyonuna $\left(64,13 \sim 72,88 \mu \mathrm{g} / \mathrm{m}^{3}\right)$ sahip olan ilimizdir. Bununla beraber, Ordu sahil kesimi $54,37 \sim 64,13 \mu \mathrm{g} / \mathrm{m}^{3}$ konsantrasyon ile üçüncü seviyedeyken Giresun, Artvin ve Rize ile Ordu'nun büyük bir kesimi en düşük konsantrasyona sahip olan yerlerdir.

Sonbahar ayları ortalamalarının kullanıldığ 1 Şekil 7'deki dağılım haritalarında, 2011 yılı sonbahar ortalaması haritası incelendiğinde, 47,05 57 $\mu \mathrm{g} / \mathrm{m}^{3}$ ile en yüksek konsantrasyonun Gümüşhane, Trabzon ve Bayburt'ta olduğu görülmektedir. Ordu ilinin büyük bir kısmı ikinci en yüksek konsantrasyona sahipken, Rize'nin güney doğu ile Artvin'in güney, kuzey-batı kesimleri üçüncü en yüksek konsantrasyon seviyesindedir $\left(31,48 \sim 38,05 \mu \mathrm{g} / \mathrm{m}^{3}\right)$. Son olarak da Artvin, Rize ve Giresun il merkezlerinde düşük konsantrasyon görülebilmektedir $\left(9,16 \sim 31,48 \mu \mathrm{g} / \mathrm{m}^{3}\right)$.

2012 yılı sonbahar ortalama değerler haritasında, en yüksek konsantrasyon seviyesinin $63,52 \sim 84,64 \mu \mathrm{g} / \mathrm{m}^{3}$ olduğu ve Gümüşhane il merkezi ile Bayburt ilinin tamamında görülmektedir. 49,25 63,52 $\mu \mathrm{g} / \mathrm{m}^{3}$ lük ikinci en yüksek konsantrasyon seviyesi ise Trabzon ilinin tamamında ve Gümüşhane'nin batı kesimlerinde görülmektedir. 37,35 49,24 $\mu \mathrm{g} / \mathrm{m}^{3}$ lük konsantrasyon miktarı ise Ordu ili tamamı ile Rize il merkezi dışında kalan bölgelerde olduğu hesaplanmıştır. Artvin ve Giresun illeri ise 8,79 37,35 $\mu \mathrm{g} / \mathrm{m}^{3}$ ' lük konsantrasyon ile en düşük PM10 kirleticisine sahip iller olmuştur.

$66,54 \sim 84,46 \mu \mathrm{g} / \mathrm{m}^{3}$ 'lük konsantrasyon değerleri ile en yüksek seviyeyi oluşturan Gümüşhane, 2013 yılı sonbahar ortalaması haritasında görülebilmektedir. Bu değerleri takiben Trabzon ve Bayburt illeri, $54,35 \sim 66,54 \mu \mathrm{g} / \mathrm{m}^{3}$ ile ikinci en yüksek konsantrasyon seviyesindedir. Ordu ilinin tamamı ve Giresun ilinin doğu, güney-doğu kesimindeki konsantrasyon seviyesi 43,59 54,35 $\mu \mathrm{g} / \mathrm{m}^{3}$ tür. Giresun il merkezi ve Rize ile Artvin illerindeki konsantrasyon seviyeleri ise $23,76 \sim 43,59 \mu \mathrm{g} / \mathrm{m}^{3}$ ile son seviyededir.

2014 yılı PM10 dağılım haritası incelendiğinde ise Trabzon, Gümüşhane ve Bayburt illerinde yüksek konsantrasyon görülebilmektedir. Bu konsantrasyon seviyelerine bakıldığında 55,68 78,16 $\mu \mathrm{g} / \mathrm{m}^{3}$ olduğu anlaşılmaktadır. Dağılım haritasında da anlaşılacağı üzere Giresun'un doğu kesimi ile Trabzon ve Bayburt'un doğu kesimleri 49,99 55,68 $\mu \mathrm{g} / \mathrm{m}^{3}$ lük PM10 konsantrasyonu nedeniyle ikinci en yüksek konsantrasyona sahip alan olmuşlardır. 40,30 49,99 $\mu \mathrm{g} / \mathrm{m}^{3}$ arasındaki değerler üçüncü en yüksek değerlerdir ve Ordu ilinin tamamı ile Giresun ilinin batı kesiminde dağılım göstermektedir. Hesaplanan en düşük dağılım ise Rize ve Artvin bölgelerindedir.

2015 yılı sonbahar ortalaması dağılım haritasında ise Gümüşhane'nin yanı sıra Ordu ili de en yüksek konsantrasyon görülen iller arasındadır. Trabzon, Gümüşhane'nin geri kalan kısmı ve Giresun batı kesimi ile Artvin ilinin doğu kesiminin konsantrasyon değerleri 45,48 51,15 $\mu \mathrm{g} / \mathrm{m}^{3}$ tür. Giresun'un büyük bir kısmı ile Artvin batı kesimi 38,99 45,48 $\mu \mathrm{g} / \mathrm{m}^{3}$ ile dağılımı oluşturmaktadır. Diğer yıllardaki sonbahar ortalamalarına nazaran 2015 yılında Bayburt en düşük konsantrasyona sahip il olmuştur.

\subsection{Kış Mevsimi Hava Kalitesi Dağılımları}

Aralık, Ocak ve Şubat aylarının PM10 ortalamaları kullanılarak yapılan kış ayları dağılım haritası Şekil 9 ve Şekil 10 da verilmektedir. Şekil 9 incelendiğinde, 2010 yılı kış ayları ortalamasının en yüksek olduğu illerin başında Trabzon, Gümüşhane ve Bayburt gelmektedir $\left(84,04 \sim 97,81 \mu \mathrm{g} / \mathrm{m}^{3}\right)$. Ordu ilinin şehir merkezinde ise yine en yüksek konsantrasyon gözlemlenmektedir. Ordu'nun geri kalan kesimi, Giresun'un Trabzon Gümüşhane sınırları ile Trabzon'un Rize sınırı ikinci en yüksek konsantrasyon seviyesindedir $\left(74,30 \sim 84,04 \mu \mathrm{g} / \mathrm{m}^{3}\right)$. Rize'nin büyük bir kesimindeki konsantrasyon seviyesi $63,78 \sim 74,30 \mu \mathrm{g} / \mathrm{m}^{3}$ aralı̆ $ı$ Iadır. Artvin ve Giresun illerinin önemli bir kısmında ise en düşük seviyede konsantrasyon bulunmaktadır.

2011 y1lı kı ortalaması PM10 konsantrasyon dağılımı haritasında ise en yüksek konsantrasyonun sadece Trabzon ve Ordu merkezlerinde olduğu görülmektedir. Yine aynı şekilde Trabzon ve Ordu ilindeki dağılımlarda 74,24 84,75 $\mu \mathrm{g} / \mathrm{m}^{31}$ lük ikinci seviye ve 64,42 74,24 $\mu \mathrm{g} / \mathrm{m}^{3}$ aralığındaki üçüncü seviye konsantrasyonlar da bulunmaktadır. Bayburt ve Gümüşhane illerinin neredeyse büyük bir kesimi üçüncü seviye konsantrasyon değerlerine sahiptir. Artvin, Rize ve Giresun illeri ise en düşük konsantrasyon görülen iller arasındadır.

2012 y1lına ait haritada ise en yüksek konsantrasyona sahip olan ilin $85,29 \sim 119,76 \mu \mathrm{g} / \mathrm{m}^{3}$ aralı̆̆ ile Trabzon olduğu Gümüşhane ilinin tamamı ve Ordu il merkezi görülen konsantrasyon seviyesinin ise $71,34 \sim 85,29 \mu \mathrm{g} / \mathrm{m}^{3}$ olduğu anlaşılmaktadır. 56,57 71,34 $\mu \mathrm{g} / \mathrm{m}^{3}$ seviyesine sahip iller arasında ise Ordu ve Bayburt gelmektedir. Rize ve Artvin illerinin tamamı ve Giresun il merkezinde en düşük PM10 konsantrasyonu görülmektedir.

Trabzon ve Gümüşhane'nin en yüksek konsantrasyon aralığına $\left(71,41 \sim 89,16 \mu \mathrm{g} / \mathrm{m}^{3}\right)$ sahip olduğu 2013 y1lı kış ortalaması haritasında Bayburt ilinin tamamı ve Ordu il merkezinde $62,77 \sim 71,41 \mu \mathrm{g} / \mathrm{m}^{3}$ aralı̆ğ ile ikinci seviyede konsantrasyon bulunmaktadır. Ordu ilinin geri kalan kesiminde, Giresun'un Gümüşhane Trabzon sınırı ile Rize'nin Trabzon sinırında görülen konsantrasyon üçüncü en yüksek konsantrasyondur ve $54,16 \sim 62,77 \mu \mathrm{g} / \mathrm{m}^{3}$ aralığındadır. Diğer yıllarda da olduğu gibi yine aynı şekilde Rize, Artvin ve Giresun illeri en düşük konsantrasyonun görüldüğü iller arasindadır. 
2014 yılına ait dağılım haritasında ise Trabzon Gümüşhane ve Bayburt illeri PM 10 kirliliği bakımından en yüksek konsantrasyona sahip iller arasındadır. 2014 yılının kış aylarında Ordu ve Giresun illerinde de yüksek PM10 konsantrasyonu görülmektedir. Rize ve Artvin illeri ise diğer yıllardaki gibi en az kirliliğe sahip illerdendir.

2015 yılı kış ortalaması haritasında ise en düşük konsantrasyonun görüldüğü iller arasında Bayburt, Rize ve Artvin gelmektedir. Trabzon'un 82,30 105,91 $\mu \mathrm{g} / \mathrm{m}^{3}$ aralığ1 ile en yüksek konsantrasyona sahipken Giresun, Gümüşhane'de ise üçüncü seviyede konsantrasyon görülmektedir.
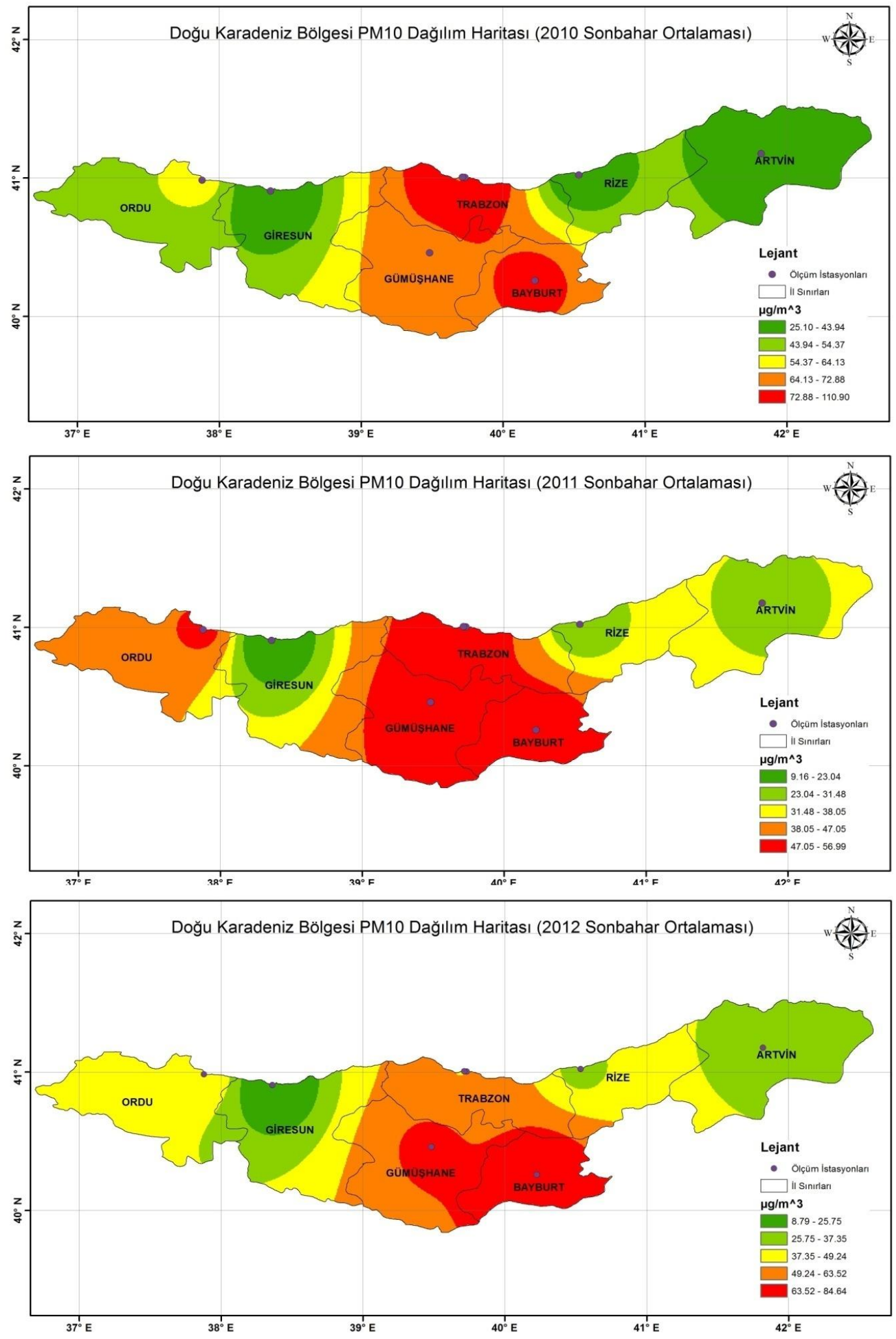

Şekil 7: Çalışma alanı sonbahar mevsimi ortalaması PM 10 dağılımları (2010-2012 yılları) 

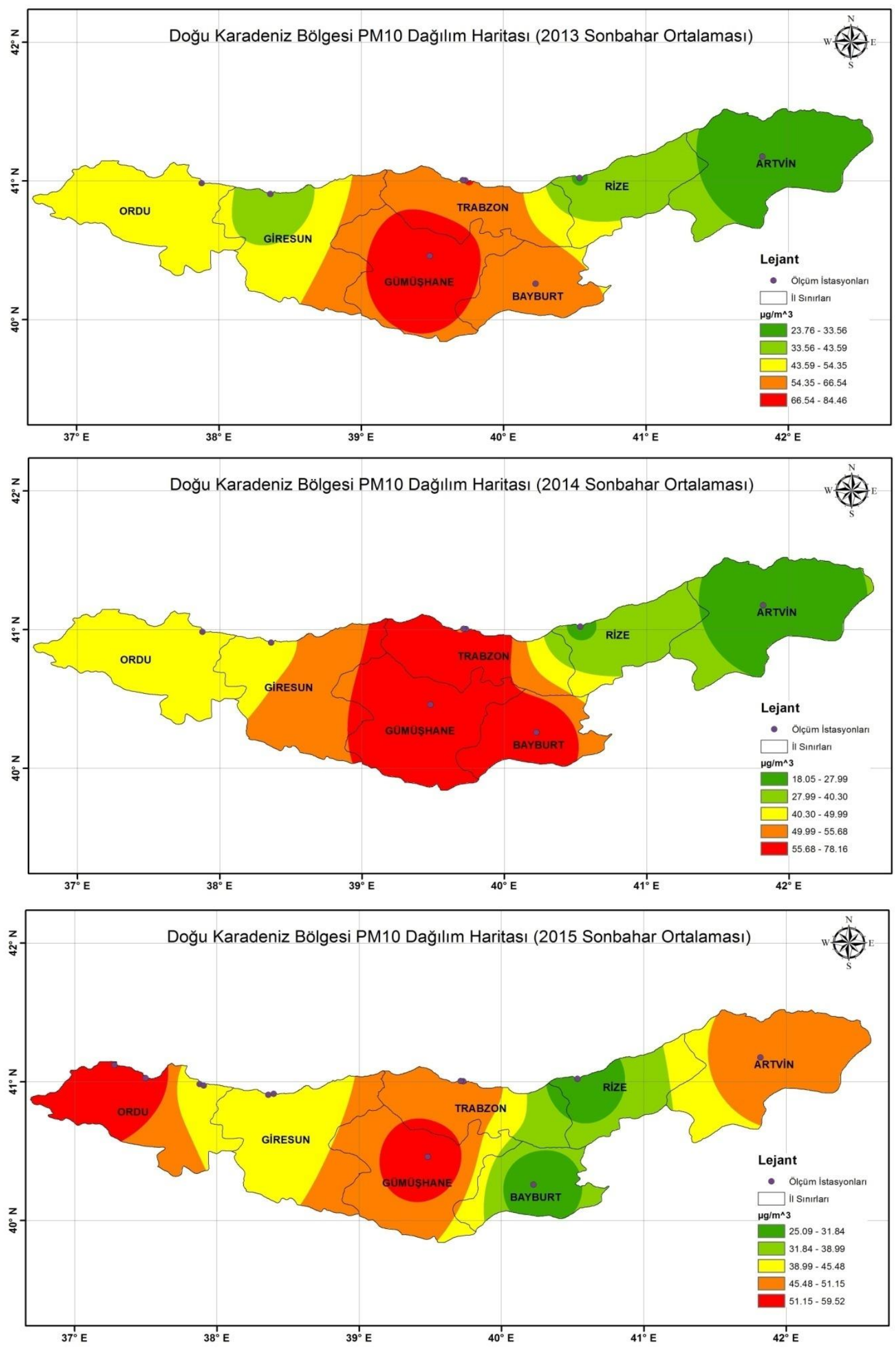

Şekil 8: Çalışma alanı sonbahar mevsimi ortalaması PM 10 dağılımları (2013-2015 yılları) 

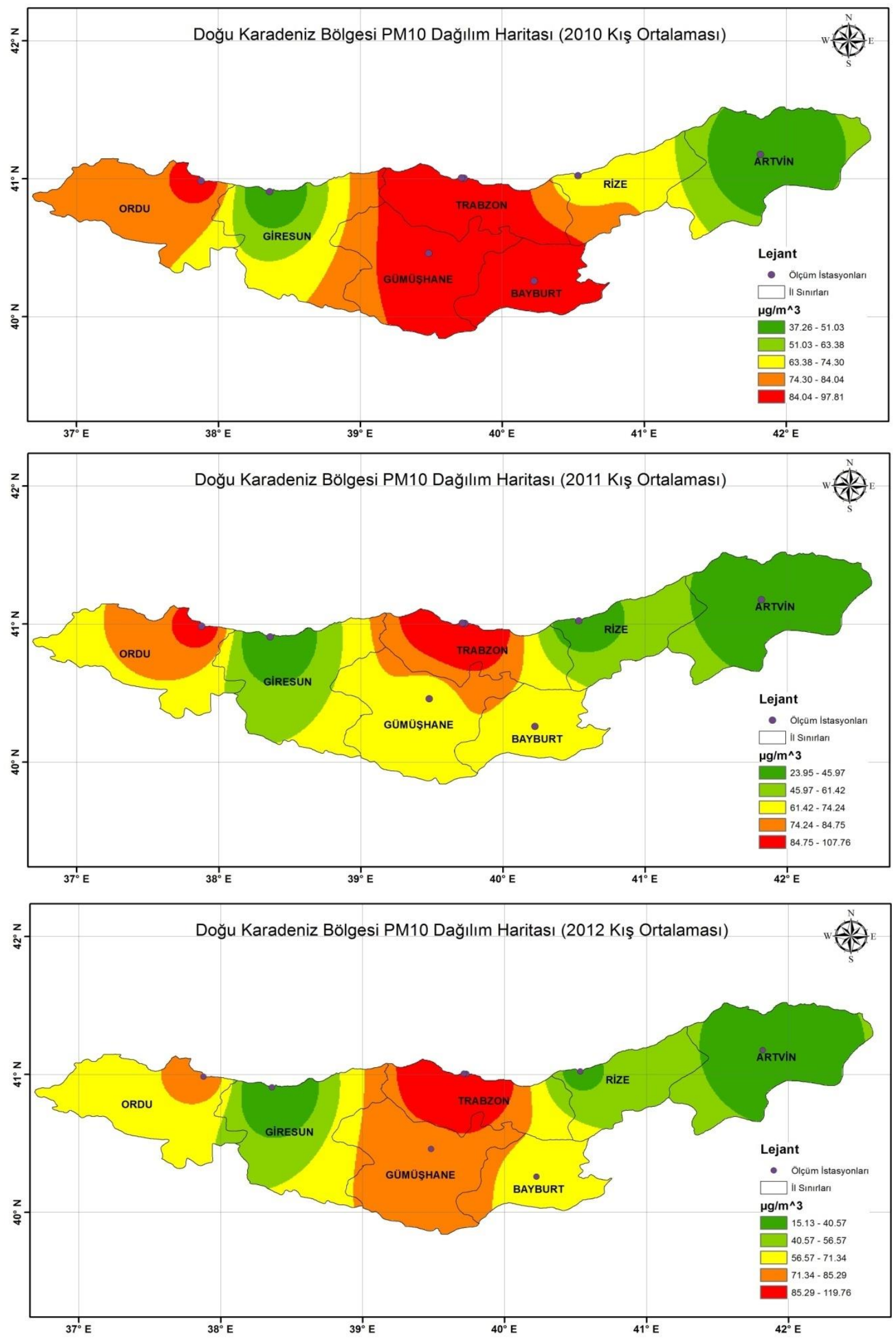

Şekil 9: Çalışma alanı kış mevsimi ortalaması PM 10 dağılımları (2010-2012 yılları) 

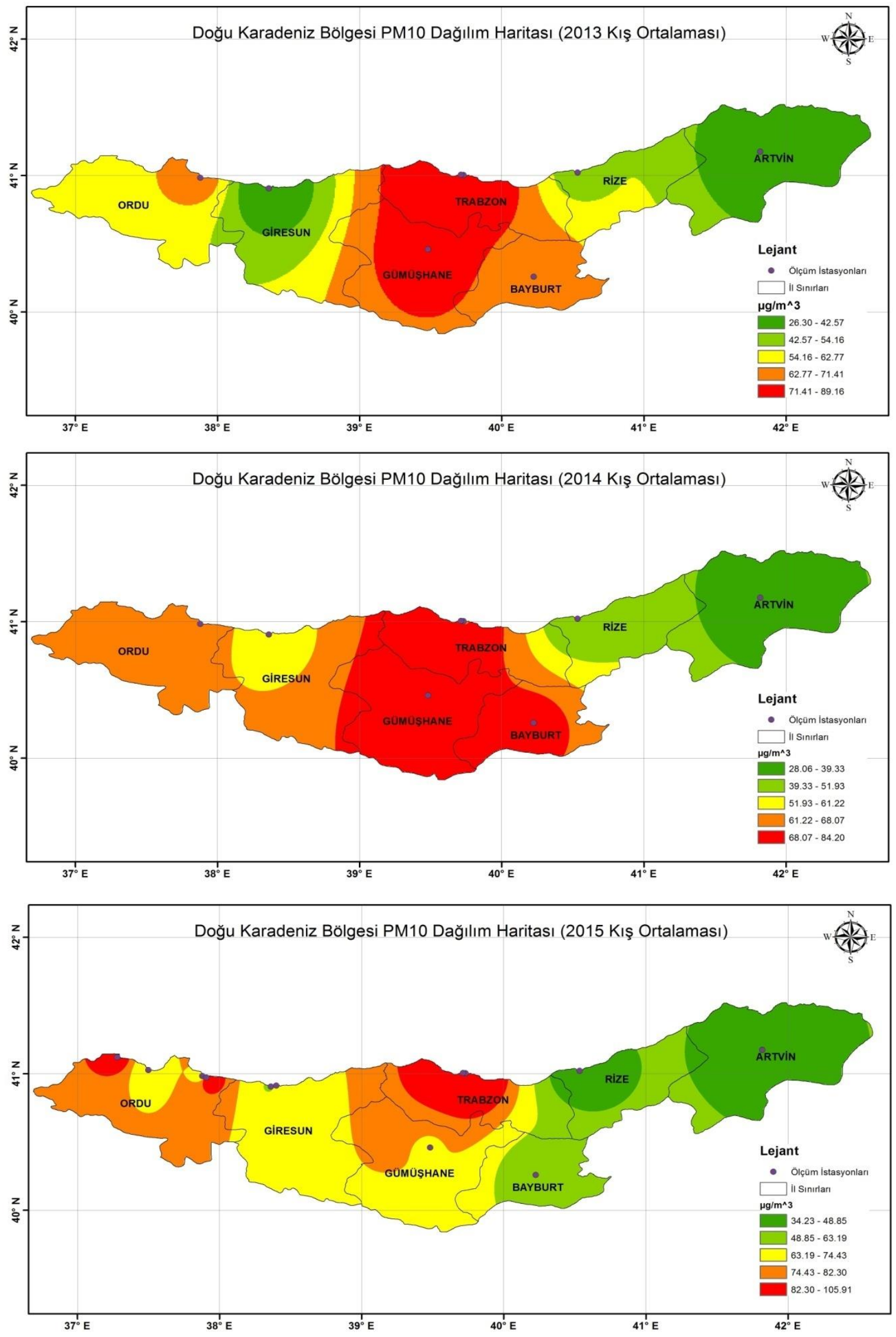

Şekil 10: Çalışma alanı kış mevsimi ortalaması PM 10 dağıımları (2013-2015 yılları) 


\section{Sonuçlar}

Doğu Karadeniz Bölgesi illerinin 2010-2015 yılları arasındaki PM10 konsantrasyonları T.C. Çevre ve Şehircilik Bakanlı̆̆ı'na ait ölçüm istasyonlarının kayıtlarından elde edilmiştir. Bu veriler ve ArcGIS 10.2.1 CBS yazılımı kullanılarak bölgeye ait PM10 dağılım haritaları oluşturulmuştur. Dağılım haritaları oluşturulurken ölçüm sonuçlarının mevsimsel ortalamaları kullanılmıştır. Ayrıca bölgede bulunan meteoroloji istasyon kayıtlarından alınan saatlik rüzgar yön ile hız verilerinden ve WRPLOT VIEW 7.0.0 programından yararlanılarak, bölgeye ait rüzgar gülleri oluşturulmuştur. Rüzgar hız ve yönleri incelendiğinde, bölgedeki hakim rüzgar yönlerinin çok farklı olduğu görülebilmektedir. Bu durum da gerçekteki PM10 konsantrasyon dağılımları üzerinde etkili olmaktadır. Ortalama rüzgar hızlarının da yine her bir ilde farklı olduğu ve dağılım üzerinde etkisinin bulunduğu anlaşılmaktadır. Bölgenin yüksek miktarda yağı̧̧ alması, topoğrafik yapısının oldukça engebeli olması ve bitki örtüsü PM10 konsantrasyonunun dağılımı üzerinde etkili olmaktadır.

Kış aylarındaki ısınma amaçlı kullanılan yakıtlar ile diğer mevsimlerde çizgisel kaynakların bölgede etkili PM10 kaynağı olarak belirlenmiştir. Bu duruma kanıt olarak kış ve sonbahar mevsimlerine ait haritalarda görülen PM10 konsantrasyonlarındaki artış gösterilebilir.

Haritalar yorumlandığında, ilkbahar mevsimine ait haritalarda en yüksek konsantrasyon seviyesine sahip iller arasında, Trabzon, Rize, Ordu ve Gümüşhane; yaz mevsimlerinde Trabzon, Gümüşhane ve Bayburt; sonbahar mevsimlerinde Trabzon, Bayburt, Gümüşhane, Ordu; kış mevsimlerinde ise yine aynı şekilde Trabzon, Bayburt, Gümüşhane ve Ordu olduğu belirlenmiştir. Ayrıca ölçüm istasyonlarının yer seçimi ölçülen konsantrasyonlar, dolayısıyla dağılım sonuçları üzerinde önemli etkilere sahiptir. Çalışma alanı içerisindeki ölçüm istasyonlarının hatalı konumlandırılması, gerçek durumdan daha düşük PM10 konsantrasyonlarının ölçülmesine yol açabilmektedir.

\section{Kaynaklar}

Aguilera I., Basagana X., Pay, T.M., Agis D., Bouso L., Foraster M., Rivera M., Baldasano J.M., Kunzli N., (2013), Evaluation of the CALIOPE air quality forecasting system for epidemiological research: The example of $\mathrm{NO}_{2}$ in the province of Girona (Spain) Inmaculada, Atmospheric Environment,72, 134-141.

Baldasano J.M., Pay M.T., Jorba O., Gasso S., Guerrero P.J., (2011), An annual assessment of air quality with the CALIOPE modeling system over Spain, The Science of the Total Environment, 409 (11), 2168-2178.

Bentayeb M., Stempfelet M., Wagner V., Zins M., Bonenfont S., Sanchez O., Rosso A., Brulfert G., Rios I., Chaxel E., Virga J., Armengaude A., Rossello P., Rivière E., Bernardg., Vasbien F., Deprost R., (2014), Retrospective modeling outdoor air pollution at a fine spatial scale in France, 1989-2008, Atmospheric Environment, 92, 267-279.

Demirarslan K.O., (2015), Air Quality Standards in Relating Environmental Problems With Standards; Examples in Turkey And in The World, 12th International Conference on Standardization, Pyrotypes, and Quality, 22-24 October 2015, Kocaeli.

Demirarslan K.O., (2016), Kış kentlerinde ısınma kaynaklı partikül maddenin hava kalitesi üzerine etkisi ve Doğu Anadolu Bölgesi A ̆grı, Ardahan, Erzurum ve Kars illeri örneği, Uluslararası Kış Kentleri Sempozyumu, 10-12 Şubat, Atatürk Üniversitesi, Erzurum.

Dimitriou A., Christidou V., (2011), Causes and Consequences of Air Pollution and Environmental Injustice as Critical Issues for Science and Environmental Education, DOİ: 10.5772/17654, www.intechopen.com, [Erişim 05 Eylül 2015]

Giannouli M., Kalagnomou E.A., Mellios G., Moussipoulos N., Samaras Z., Fiala J., (2011), Impact of European emission control strategies on urban and local air quality, Atmospheric Environment, 45, 4753 - 4762.

Guttikunda S.K., Jawahar P., (2012), Application of SIM-air modeling tools to assess air quality in Indian cities, Atmospheric Environment, 62, 551-561.

Parrish D.D., Singh H.B., Molina L., Madronich S., (2011), Air quality progress in North American megacities: A review, Atmospheric Environment, 45, 7015-7025.

Russo A. Trigo R.M., Hartins H. Mendes M.T., (2014), $\mathrm{NO}_{2}, \mathrm{PMIO}_{\text {and }} \mathrm{O}_{3}$ urban concentrations and its association with circulation weather types in Portugal, Atmospheric Environment, 89, 768-785.

URL-1, (2016), Conserve-Energy-Future, What is Air pollution? http://www.conserve-energy-future.com/causes-effects-solutionsof-air-pollution.php [Erişim 10 Ocak 2016].

URL-2, (2016), British Columbia, What is air quality? http://www.bcairquality.ca/101/what-is-air-quality.html [Erişim 10 Ocak 2016].

URL-3, (2012), Artvin İl Çevre Durum Raporu, http://www.csb.gov.tr/db/ced/editordosya/artvin_icdr2012.pdf [Erişim 05 Eylül 2015].

URL-4, (2013), Artvin İl Çevre Durum Raporu, http://www.csb.gov.tr/db/ced/editordosya/Artvin_icdr2013.pdf [Erişim 22 Eylül 2015].

URL-5, (2014), Artvin İl Çevre Durum Raporu, http://www.csb.gov.tr/db/ced/editordosya/Artvin_icdr2014.pdf [Erişim 10 Eylül 2015].

URL-6, (2011), Bayburt İl Çevre Durum Raporu, http://cdr.cevre.gov.tr/2011/bayburt_icdr2011.pdf [Erişim 19 Eylül 2015].

URL-7, (2012), Bayburt İl Çevre Durum Raporu, http://www.csb.gov.tr/db/ced/editordosya/Bayburt_icdr2012.pdf [Erişim 19 Eylül 2015].

URL-8, (2013), Bayburt İl Çevre Durum Raporu, http://www.csb.gov.tr/db/ced/editordosya/Bayburt_icdr2013.pdf [Erişim 19 Eylül 2015].

URL-9, (2014), Bayburt İl Çevre Durum Raporu, http://www.csb.gov.tr/db/ced/editordosya/Bayburt_icdr2014.pdf [Erişim 19 Eylül 2015]. 
URL-10, (2011), Giresun İl Çevre Durum Raporu, http://www.csb.gov.tr/turkce/dosya/ced/icdr2011/ giresun_icdr2011.pdf [Erişim 19 Eylül 2015].

URL-11, (2012), Giresun İl Çevre Durum Raporu, http://www.csb.gov.tr/db/ced/editordosya/giresun_icdr2012(1).pdf [Erişim 19 Eylül 2015].

URL-12, (2013), Giresun İl Çevre Durum Raporu, http://www.csb.gov.tr/db/ced/editordosya/Giresun_icdr2013.pdf [Erişim 19 Eylül 2015].

URL-13, (2014), Giresun İl Çevre Durum Raporu, http://www.csb.gov.tr/db/ced/editordosya/Giresun_icdr2014.pdf [Erişim 19 Eylül 2015].

URL-14, (2010), Gümüşhane İl Çevre Durum Raporu, http://cdr.cevre.gov.tr/2010/gumushaneicd2010.pdf [Erișim 19 Eylül 2015]

URL-15, (2011), Gümüşhane İl Çevre Durum Raporu, http://www.csb.gov.tr/db/ced/editordosya/ gumushane_icdr2011.pdf [Erişim 19 Eylül 2015].

URL-16, (2012), Gümüşhane İl Çevre Durum Raporu, http://www.csb.gov.tr/db/ced/editordosya /gumushane_icdr2012(1).pdf [Erişim 19 Eylül 2015].

URL-17, (2013), Gümüşhane İl Çevre Durum Raporu, http://www.csb.gov.tr/db/ced/editordosya/ Gumushane_icdr2013.pdf [Erişim 19 Eylül 2015].

URL-18, (2014), Gümüşhane İl Çevre Durum Raporu, http://www.csb.gov.tr/db/ced/editordosya/ Gumushane_icdr2014.pdf [Erişim 19 Eylül 2015].

URL-19, (2011), Ordu İl Çevre Durum Raporu, http://cdr.cevre.gov.tr/2011/ordu_icdr2011.pdf [Erişim 19 Eylül 2015].

URL-20, (2012), Ordu İl Çevre Durum Raporu, http://www.csb.gov.tr/db/ced/editordosya/Ordu_icdr2012.pdf [Erişim 19 Eylül 2015].

URL-21, (2013), Ordu İl Çevre Durum Raporu, http://www.csb.gov.tr/db/ced/editordosya/Ordu_icdr2013.pdf [Erişim 19 Eylül 2015].

URL-22, (2010), Rize İl Çevre Durum Raporu, http://cdr.cevre.gov.tr/2010/rizeicd2010.pdf [Erişim 19 Eylül 2015].

URL-23, (2011), Rize İl Çevre Durum Raporu, http://www.csb.gov.tr/db/ced/editordosya/rize_icdr2011.pdf [Erişim 19 Eylül 2015].

URL-24, (2012), Rize İl Çevre Durum Raporu, http://www.csb.gov.tr/db/ced/editordosya/Rize_icdr2012.pdf [Erișim 19 Eylül 2015].

URL-25, (2013), Rize İl Çevre Durum Raporu, http://www.csb.gov.tr/db/ced/editordosya/Rize_icdr2013.pdf [Erişim 19 Eylül 2015].

URL-26, (2014), Rize İl Çevre Durum Raporu, http://www.csb.gov.tr/db/ced/editordosya/Rize\%202014.pdf [Erișim 19 Eylül 2015 ].

URL-27 (2010), Trabzon İl Çevre Durum Raporu, http://cdr.cevre.gov.tr/2010/trabzonicd2010.pdf [Erişim 19 Eylül 2015].

URL-28, (2011), Trabzon İl Çevre Durum Raporu, http://www.csb.gov.tr/iller/dosyalar/dosya/il_webmenu11573.pdf [Erişim 19 Eylül 2015].

URL-29, (2012), Trabzon İl Çevre Durum Raporu, http://www.csb.gov.tr/db/ced/editordosya/Trabzon_icdr2012.pdf [Erişim 19 Eylül 2015].

URL-30, (2013), Trabzon İl Çevre Durum Raporu, http://www.csb.gov.tr/db/ced/editordosya/Trabzon_icdr2013.pdf [Erişim 19 Eylül 2015].

URL-31, (2014), Trabzon İl Çevre Durum Raporu, http://www.csb.gov.tr/db/ced/editordosya/Trabzon\%202014.pdf [Erişim 19 Eylül 2015].

URL-32, (2016), Lakes Environmental, WRPLOT View Overview, http://www.weblakes.com/products/wrplot/ [Erişim 10 Ocak 2016]. 